DOI: https://doi.org/10.24127/ajpm.v10i2.3515

\title{
PENGEMBANGAN MODUL PEMBELAJARAN MATRIKS BERBANTUAN APLIKASI GEOGEBRA
}

\author{
Orin Asdarina $^{1 *}$, Husnul Khatimah ${ }^{2}$ \\ ${ }^{1 *}, 2$ Pendidikan Matematika, STKIP Muhammadiyah Aceh Barat Daya, Indonesia. \\ *Corresponding author. Aceh Barat Daya, Aceh, Indonesia. \\ E-mail: $\quad$ orin.asdarina@gmail.com ${ }^{1 *}$ \\ husnulkhatimah.mtk@gmail.com ${ }^{2)}$
}

Received 28 January 2021; Received in revised form 16 June 2021; Accepted 02 July 2021

\begin{abstract}
Abstrak
Penelitian ini bertujuan untuk menghasilkan modul pembelajaran matriks berbantuan aplikasi Geogebra yang valid, praktis, dan efektif di SMA Negeri Unggul Harapan Persada. Jenis penelitian ini adalah penelitian pengembangan yang mengacu pada model ADDIE yang terdiri dari lima tahapan yaitu Analysis (analisis), Design (desain), Development (pengembangan), Implementation (implementasi), dan Evaluation (evaluasi). Subjek uji coba pada penelitian ini adalah siswa kelas XI IPS SMA Negeri Unggul Harapan Persada tahun ajaran 2020/2021. Hasil validasi oleh team expert maka modul pembelajaran matriks berbantuan aplikasi GeoGebra masuk dalam kategori valid dengan skor rata-rata 4.5 (Sangat Baik). Berdasarkan hasil ujicoba lapangan, respon yang diberikan siswa diperoleh persentase rata-rata $82,6 \%$ dengan klasifikasi sangat baik. Hal ini menunjukkan bahwa modul pembelajaran matriks berbantuan GeoGebra membantu dan memudahkan siswa dalam memahami materi matriks. Kemudian hasil observasi keterlaksanaan pembelajaran yang diberikan oleh observer diperoleh persentase rata-rata $83,33 \%$ dengan kategori praktis. Hal ini menunjukkan bahwa perangkat pembelajaran yang dikembangkan praktis digunakan dalam proses pembelajaran.Berdasarkan tes hasil belajar siswa, siswa yang tuntas sebanyak $85,7 \%$ yang artinya hasil dari penerapan modul pembelajaran matriks berbantuan aplikasi Geogebra efektif untuk digunakan dalam pembelajaran di kelas.
\end{abstract}

Kata kunci: GeoGebra; modul; pembelajaran matriks.

\begin{abstract}
This study aims to produce a valid, practical, and effective GeoGebra-assisted matrix learning module at SMA Negeri Unggul Harapan Persada. This type of research is development research that refers to the ADDIE model, which consists of five stages, namely analysis, design, development, implementation, and evaluation. The subjects in this study were students of class XI IPS at SMA Negeri Unggul Harapan Persada in the academic year of 2020/2021. The results of the validation by the expert team, the GeoGebra-assisted matrix learning module was embodied in the explicit category with an average score of 4.5 (very good). Based on the results of field trials, the responses given by students obtained an average percentage of $82.6 \%$ with a very good classification. The results showed that the GeoGebraassisted matrix learning module helped students to understand the matrix material. Then the results observations of the learning activities obtained an average percentage of $83.33 \%$ with the practical category. The result showed that the developed learning media was practically used in the learning process. Based on the test of student learning outcomes, as many as $85.7 \%$ of students passed the test, which meant the results of the GeoGebra-assisted matrix learning module were eligible to be used in the classroom learning.
\end{abstract}

Keywords: GeoGebra; matrix learning; module.

This is an open access article under the Creative Commons Attribution 4.0 International License

\section{PENDAHULUAN}

Seiring dengan perkembangan ilmu pengetahuan dan teknologi yang

sangat berpengaruh terhadap
pendidikan, peningkatan


diprioritaskan oleh pemerintah. Untuk mendukung hal tersebut,pemanfaatan sumber belajar lain selain yang tersedia di sekolah juga dapat dilakukan guru demi menunjang proses belajar mengajar.

Pemanfaatan teknologi dalam proses belajar biasanya dilaksanakan dengan pengaplikasian komputer, dengan memanfaaatkan aplikasi komputer siswa dapat memahami materi dengan mudah, karena siswa akan melihat langsung visual yang ditampilkan dengan jelas, dan siswa dapat mengulang kembali materi yang belum bisa dipahami dengan baik secara mandiri.

Siswa di abad ke-21 sudah melek komputer seperti siswa menggunakan Internet, ponsel, komputer, laptop, tablet, dan perangkat lunak lainnya untuk berkomunikasi dengan orang lain. Lingkungan digital seperti ini yang memotivasi siswa dalam pengajaran dan pembelajaran Matematika (Korenova, 2017).

Salah satu aplikasi yang dapat dimanfaatkan sebagai media pembelajaran matematika adalah GeoGebra. Menurut (Mahmudi, 2011), GeoGebra dimanfaatkan sebagai media pembelajaran matematika untuk mendemonstrasikan atau memvisualisasikan konsep-konsep matematis serta sebagai alat bantu untuk mengkontruksi konsep-konsep matematis.

Kemudian (Arbain \& Shukor, 2015) mengungkapkan bahwa Software GeoGebra memiliki dampak positif pada prestasi siswa, Software GeoGebra juga harus diperkenalkan kepada pendidik Matematika sehingga siswa dapat menjelajahi dunia Matematika secara lebih luas dan membuat siswa mampu berpikir kritis dan kreatif.
Berdasarkan hasil observasi awal dengan guru matematika di SMA Negeri Unggul Harapan Persada, di peroleh informasi bahwasanya banyak siswa yang mengalami kesulitan dalam mengerjakan soal-soal determinan matriks berordo 3 dan invers dari matriks. Selain itu, pada proses pembelajaran guru mengajar masih fokus pada penggunaan buku paket dan belum ada pengembangan modul pembelajaran terutama modul pembelajaran matriks berbantuan GeoGebra. Hal ini dikarenakan guru di Sekolah tersebut belum memanfaatkan aplikasi GeoGebra dalam pembelajaran matriks.

Telah dilakukan beberapa penelitian terkait pengembangan modul pembelajaran yang digunakan untuk mempermudah proses pembelajaran, seperti penelitian yang telah dilakukan (Ekayanti, 2017) dengan hasil penelitiannya yaitu pengembangan modul irisan kerucut berbantuan Geogebra memenuhi kriteria valid, praktis dan efektif. Kemudian penelitian yang dilakukan oleh (Aminah \& Radita, 2020; Rafiyanti, 2017; Zaningsih, 2018) telah melakukan penelitian tentang pengembangan modul pembelajaran materi matriks. (Sari, Farida, \& Syazali, 2016) dengan hasil penelitiannya yaitu media pembelajaran (modul) berbantuan Geogebra yang dikembangkan mendapat penilaian untuk kategori menarik dan layak dijadikan sebagai media pembelajaran untuk SMA kelas XI pada pokok bahasan turunan. Namun, belum ada penelitian sebelumnya yang mengembangkan modul pembelajaran matriks berbantuan Geogebra.

Oleh karena itu, untuk membantu siswa dalam memahami materi matriks dengan baik dan mudah serta mengatasi berbagai macam persoalan mengenai 
materi matriks, perlu kiranya dikembangkan suatu modul pembelajaran matriks dengan bantuan suatu aplikasi yang mudah dioperasikan oleh siswa maupun guru.

Dengan demikian dikembangkan modul pembelajaran matriks berbantuan GeoGebra yang nantinya dapat membantu siswa memecahkan berbagai permasalahan yang terdapat dalam pembelajaran matriks. Modul ini untuk siswa kelas XI SMA/sederajat.

Tujuan dari penelitian ini adalah mengembangkan modul pembelajaran matriks berbantuan aplikasi GeoGebra di SMA Negeri Unggul Harapan Persada yang memenuhi kriteria valid, praktis dan efektif.

\section{METODE PENELITIAN}

Jenis penelitian yang dilakukan adalah penelitian pengembangan. Penelitian ini menggunakan model pengembangan ADDIE (Analysis, Design, Develop, Implementation, Evaluation). Modul pembelajaran dikatakan berkualitas apabila memenuhi tiga kriteria yaitu kevalidan, kepraktisan dan keefektifan, Nieeven (Rochmad, 2012). Oleh karena itu, langkah-langkah penelitian yang dilakukan meliputi:

\section{Analysis}

Analisis yang dilakukan adalah mencakup needs assessment (analisis kebutuhan), analisis materi, kurikulum dan analisis karakteristik siswa.

\section{Design}

Merancang modul yang meliputi materi, lembar kerja siswa (LKS), dan soal tes pembelajaran pada materi matriks berbantuan aplikasi GeoGebra.

\section{Development}

Mengembangkan

modul

pembelajaran matriks dengan berbantuan aplikasi GeoGebra berdasarkan validasi ahli dan revisi produk tahap 1 .

\section{Implementation}

Mengujicobakan

modul pembelajaran matriks berbantuan aplikasi GeoGebra kepada siswa. Mengujicobakan LKS, melaksanakan tes hasil belajar, dan membagikan angket respon.

\section{Evaluation}

Melakukan analisis serta perbaikan terhadap kesalahan yang terjadi selama pembelajaran pada tahap implementasi.

Subjek dalam penelitian ini adalah siswa kelas XI IPS SMA Negeri Unggul Harapan Persada tahun ajaran 2020/2021 yang berjumlah 14 orang siswa. Teknik pengumpulan data pada penelitian ini, yaitu berupa instrumen penelitian yang digunakan untuk penilaian kevalidan adalah lembar validasi modul.Lembar validasi ini ditujukan kepada team expert yaitu 2 dosen ahli (ahli materi matriks dan GeoGebra, ahli media) serta 2 guru mata pelajaran matematika, lembar validasi ini menentukan apakah modul pembelajaran layak digunakan tanpa revisi, dengan revisi atau tidak layak diproduksi.

Instrumen penilaian kepraktisan berupa Angket Respon Siswa dan Lembar observasi kegiatan pembelajaran. Sedangkan instrumen yang digunakan untuk mengukur keefektifan yaitu Tes hasil belajar.Tes yang disusun adalah tes hasil belajar berbentuk soal tes. Soal tes diberikan untuk melihat hasil akhir belajar siswa setelah menggunakan modul pembelajaran matriks berbantuan aplikasi GeoGebra.

Teknik analisis data dalam penelitian ini terbagi menjadi beberapa tahapan yaitu: 
DOI: https://doi.org/10.24127/ajpm.v10i2.3515

\section{Tahap Analisis kevalidan}

Analisis kevalidan dilakukan dengan mencari rata-rata dari lembar validasi materi dan media yang telah divalidasi oleh team expert. Pedoman klasifikasi penilaian kevalidan dapat dilihat pada Tabel 1.

Tabel 1. Pedoman klasifikasi penilaian kevalidan modul pembelajaran

\begin{tabular}{cc}
\hline Interval Skor & Kriteria \\
\hline $\bar{x}>4,20$ & Sangat Baik \\
$3,4<\bar{x} \leq 4,20$ & Baik \\
$2,6<\bar{x} \leq 3,4$ & Cukup \\
$1,8<\bar{x} \leq 2,6$ & Kurang \\
$\bar{x} \leq 1,8$ & Sangat Kurang \\
\hline
\end{tabular}

Modul pembelajaran yang dikembangkan dikatakan valid apabila skor rata-rata penilaiain kevalidan masing-masing memenuhi kriteria minimal baik. Jika kurang dari nilai yang sudah ditetapkan maka modul pembelajaran perlu direvisi kembali.

\section{Tahap Analisis Kepraktisan}

a) Angket Respon Siswa

Kriteria Respon Siswa dapat dilihat dalam Tabel 2.

Tabel 2. Kriteria respon siswa terhadap pernyataan berdasarkan nilai persentase

\begin{tabular}{cc}
\hline $\begin{array}{c}\text { Rentang Nilai } \\
(\boldsymbol{\%})\end{array}$ & Kategori Respon \\
\hline $25-50$ & Siswa \\
$51-75$ & Kurang Baik \\
$76-100$ & Cukup Baik \\
\hline
\end{tabular}

Modul pembelajaran matriks dikatakan memiliki derajat kepraktisan, jika respon siswa berada pada kriteria baik.

b) Observasi Kegiatan Pembelajaran

Kriteria observasi kegiatan pembelajaran dapat dilihat pada Tabel 3. Modul pembelajaran matriks dikatakan memiliki derajat kepraktisan, jika observasi pembelajaran minimal berada pada kriteria baik. Jika kurang dari kriteria yang sudah ditetapkanmaka perlu direvisi dan diujicobakan kembali.

Tabel 3. Kriteria kepraktisan berdasarkan observasi pembelajaran

\begin{tabular}{cc}
\hline$\%$ Keterlibatan & Kepraktisan \\
\hline $0 \leq \mathrm{n}<21$ & Tidak Baik \\
$21<\mathrm{n}<41$ & Kurang Baik \\
$41 \leq \mathrm{n}<61$ & Cukup Baik \\
$61 \leq \mathrm{n}<81$ & Baik \\
$81 \leq \mathrm{n}<100$ & Sangat Baik \\
\hline
\end{tabular}

Modul pembelajaran matriks dikatakan memiliki derajat kepraktisan, jika observasi pembelajaran minimal berada pada kriteria baik. Jika kurang dari kriteria yang sudah ditetapkanmaka perlu direvisi dan diujicobakan kembali.

\section{Tahap Analisis Keefektifan}

Analisis keefektifan modul dapat dilihat dengan menggunakan hasil tes belajar siswa. Pedoman Keefektifan Hasil Belajar dapat dilihat pada Tabel 4.

Tabel 4. Pedoman keefektifan hasil belajar

\begin{tabular}{cc}
\hline \% ketuntasan $(\mathbf{p})$ & Efektifitas \\
\hline $0 \leq \mathrm{p}<21$ & Sangat rendah \\
$41<\mathrm{p}<56$ & Rendah \\
$56 \leq \mathrm{p}<66$ & Cukup \\
$66 \leq \mathrm{p}<80$ & Tinggi \\
$80 \leq \mathrm{p}<100$ & Sangat tinggi \\
\hline
\end{tabular}

Modul pembelajaran yang dikembangkan dikatakan efektif apabila persentase hasil belajar siswa minimal mencapai kriteria tinggi.

\section{HASIL DAN PEMBAHASAN}

Pengembangan Modul

Langkah-langkah yang dilakukan pada tahap pengembangan modul pembelajaran matriks berbantuan GeoGebra adalah sebagai berikut: 
DOI: https://doi.org/10.24127/ajpm.v10i2.3515

\section{A. Analysis (Analisis)}

Pada tahap ini dilakukan analisis kebutuhan (need assessment) dan permasalahan siswa, analisis kurikulum, analisis materi dan analisis karakteristik siswa.

1) Analisis Kebutuhan (need
assessment) dan Permasalahan
Siswa

Analisis kebutuhan merupakan langkah yang diperlukan untuk menentukan kemampuan-kemampuan atau kompetensi yang perlu dipelajari oleh siswa untuk meningkatkan hasil belajar siswa. Hasil analisis kebutuhan dan permasalahan siswa diperoleh deskripsi berikut. 1) selama ini pembelajaran matriks di sekolah terfokus pada buku paket yang telah tersedia dan video pembelajaran. 2) siswa mengalami kesulitan dalam memahami materi matriks khususnya pada bagian menentukan perkalian, determinan dan invers matriks ordo $3 \times 3$. 3) guru mata pelajaran Matematika telah mengenal dan mampu mengoperasikan aplikasi Geogebra, namun belum pernah menerapkan dalam pembelajaran matriks. 4) guru di sekolah belum pernah menerima modul pembelajaran matriks berbantuan Geogebra. 5) perlu dikembangkan suatu modul pembelajaran khususnya pada matriks berbantuan Geogebra yang berpusat pada siswa, dimana siswa aktif dalam pembelajaran dan penggunaan aplikasi tanpa mengesampingkan konsep yang diajarkan, sehingga mempermudah siswa dalam memahami materi matriks.

\section{2) Analisis Kurikulum}

Analisis kurikulum dilakukan untuk memetakan Kompetensi Inti (KI) dan Kompetensi Dasar (KD) yang berkaitan dengan penyusunan modul sebagai dasar dalam membuat indikator dan tujuan pembelajaran yang akan dicapai. Hasil analisis kurikulum dapat dijabarkan sebagai berikut: kurikulum yang digunakan di SMA Negeri Harapan Persada adalah kurikulum 2013, serta pemanfaatan teknologi informasi/ komunikasi yang sudah sedemikian canggih untuk menunjang keberhasilan pembaruan strategi dan teknik pembelajaran. Sehingga guru maupun siswa harus mampu mengikuti perkembangan teknologi dan menggunakannya dalam proses pembelajaran agar pembelajaran yang konvensional yang biasanya berpusat pada guru, sedikit demi sedikit menjadi pembelajaran yang berpusat pada siswa, agar siswa terlibat aktif dalam proses pembelajaran.

\section{3) Analisis Materi}

Analisis materi dilakukan untuk mengetahui proses pembelajaran yang biasanya dilakukan untuk menyampaikan materi matriks. Dari hasil analisis materi dapat dijabarkan sebagai berikut : 1) kesulitan konsep yang dialami siswa dalam mempelajari matriks yaitu konsep perkalian, determinan dan invers matriks ordo $3 \times 3$. 2) tingkat kemampuan siswa dalam memahami matriks secara umum sudah baik, walaupun masih ada beberapa siswa yang perlu dibimbing kembali. 3) konsep yang perlu diajarkan kepada siswa supaya siswa lebih memahami materi matriks yaitu operasi bilang positif dan negatif serta konsep pecahan. 4) secara umum guru menggunakan pembelajaran kooperatif dalam mengajarkan materi matriks dengan berpedoman pada buku paket atau video pembelajaran.

4) Analisis Karakteristik Siswa.

Pengamatan yang dilakukan selama pembelajaran di SMA Negeri Harapan Persada menunjukkan bahwa 
siswa hanya mendengarkan apa yang disampaikan oleh guru tanpa mencari referensi lain terkait materi yang diajarkan. Beberapa siswa aktif menjawab pertanyaan yang diajukan guru, namun jarang sekali ada siswa yang mau bertanya. Pembelajaran yang seharusnya berpusat pada siswa terlihat kaku, karena kurangnya interaksi antara siswa dengan guru, hanya guru saja yang dominan melakukan interaksi dengan siswa.

Berdasarkan hasil analisis kebutuhan dan permasalahan siswa, analisis kurikulum, analisis materi serta analisis karakteristik siswa diatas, maka dapat dijadikan pedoman untuk merancang modul pembelajaran matriks berbatuan aplikasi Geogebra.

\section{B. Design (Perancangan)}

Tahap perancangan modul ini dilakukan dengan langkah-langkah sebagai berikut:

\section{1) Rancangan Modul}

Modul dirancang dengan memanfaatkan aplikasi Geogebra dalam pembelajaran matriks. Dalam modul ini materi matriks dibagi menjadi 3 bagian. Bagian 1 yaitu pengenalan aplikasi Geogebra dan matriks. Pada bagian ini siswa diharapkan mampu membuat suatu matriks dengan bantuan aplikasi Geogebra. Bagian 2 yaitu melakukan operasi pada matriks yang meliputi penjumlahan, pengurangan, perkalian skalar, perkalian, dan transpose. Bagian 3 yaitu determinan dan invers matriks ordo $2 \times 2$ dan $3 \times 3$.

Pada setiap pendahuluan bab, dijelaskan kegiatan pembelajaran yang akan dilakukan. Pertama, penjelasan materi disusun dengan kalimat yang mudah dipahami, kemudian disajikan contoh dalam kehidupan sehari-hari. Dari contoh yang diberikan, lalu siswa diminta untuk menemukan konsep keterkaitan antara materi matriks dengan persamaan linear. Selanjutnya ditampilkan lagkah-langkah pengunaan Geogebra disertai dengan gambar printscreen dari layar kerja Geogebra sehingga siswa mudah mengikuti langkah-langkah yang diberikan.

Kedua, setiap akhir bagian diberikan Lembar Kerja Siswa (LKS) yang bertujuan untuk mengetahui pemahaman siswa terkait materi yang disampaikan. Permasalahan dalam LKS disusun dengan mengaikatkan kedalam kehidupan sehari-hari. Proses penyelesaian masalah dalam LKS dilakukan dengan dua cara yaitu cara seperti biasa atau manual kemudian di check dengan menggunakan aplikasi Geogebra.

\section{2) Isi Modul}

Modul yang dikembangkan terdiri atas : 1) sampul/cover modul. Sampul/cover modul dirancang dengan memuat judul modul dan identitas penulis modul serta dilengkapi dengan gambar Geogebra dan matriks. 2) kata pengantar modul. 3) daftar isi. 4) petunjuk penggunaan modul. Berisi petunjuk untuk siswa sehingga dapat dengan mudah mengunakan modul yang dikembangkan. 5) diagram alir. 6) kegiatan pembelajaran. 7) rangkuman. 8) refleksi. 9) Lembar Kerja Siswa (LKS). 10) daftar pustaka.

\section{Development (Pengembangan) \\ 1) Analisis Uji Validasi}

Data hasil validasi oleh 4 team expert ditabulasi dalam bentuk tabel dan kemudian dihitung rata-rata skor dari semua validator. Proses validasi dilakukan sekali dan direvisi sesuai dengan saran dari validator. Hasil tabulasi dari validasi oleh ahli materi dapat dilihat pada Tabel 5, sedangkan untuk ahli media dapat dilihat pada Tabel 6. 
DOI: https://doi.org/10.24127/ajpm.v10i2.3515

Tabel 5. Analisis validasi ahli materi

\begin{tabular}{llcc}
\hline No & $\begin{array}{c}\text { Indikator } \\
\text { Penilaian }\end{array}$ & $\begin{array}{c}\text { Rata- } \\
\text { rata }\end{array}$ & Kriteria \\
\hline 1 & $\begin{array}{l}\text { Kesesuaian } \\
\text { materi dengan }\end{array}$ & 4.3 & $\begin{array}{c}\text { Sangat } \\
\text { Baik }\end{array}$ \\
& $\begin{array}{l}\text { KD dan } \\
\text { Indikator }\end{array}$ & 4.5 & $\begin{array}{c}\text { Sangat } \\
\text { Baik } \\
2\end{array}$ \\
$\begin{array}{l}\text { Keakuratan } \\
\text { Materi }\end{array}$ & 4.4 & $\begin{array}{c}\text { Sangat } \\
\text { Baik } \\
\text { Kemuthakiran }\end{array}$ \\
4 & $\begin{array}{l}\text { Kesesuaian } \\
\text { dengan } \\
\text { GeoGebra }\end{array}$ & 5 & Baik \\
\hline Total & $\mathbf{4 . 5}$ & $\begin{array}{c}\text { Sangat } \\
\text { Baik }\end{array}$ \\
\hline
\end{tabular}

Tabel 6. Analisis data validasi ahli media

\begin{tabular}{clcc}
\hline No & $\begin{array}{l}\text { Indikator } \\
\text { Penilaian }\end{array}$ & $\begin{array}{c}\text { Rata- } \\
\text { rata }\end{array}$ & Kriteria \\
\hline 1 & $\begin{array}{l}\text { Kelayakan } \\
\text { Penyajian }\end{array}$ & 4.5 & Sangat Baik \\
2 & $\begin{array}{l}\text { Kelayakan } \\
\text { Bahasa } \\
\text { Kelayakan }\end{array}$ & 4.7 & Sangat Baik \\
3 & Kegrafikaan & 4.4 & Sangat Baik \\
\hline & Total & $\mathbf{4 . 5}$ & Sangat Baik \\
\hline
\end{tabular}

Berdasarkan Tabel 5 dan 6. dapat disimpulkan bahwa modul memenuhi kategori valid dan sudah dapat digunakan untuk tahap uji coba. Akan tetapi, terdapat beberapa bagian yang harus direvisi sesuai saran validator yang dapat dilihat pada Tabel 7.

Tabel 7. Hasil revisi modul pembelajaran pada tahap validasi

\section{Rancangan Awal}

Tampilan warna pada diagram alir sebaiknya diganti dengan warna yang lebih terang, karena terlihat kurang jelas

Cover modul ditambahkan gambar matriks dan judul modul disesuaikan dengan judul penelitian

Pada modul hal 8, sebaiknya pada contoh dijelaskan yang mana baris dan kolom, kaitkan dengan definisi

Hal 9, tambahkan definisi ordo

Soal LKS sebaiknya dibuat dalam bentuk permasalahan dalam kehidupan sehingga siswa diajak untuk membuat model matriks dari masalah yang diberikan.

Masih kurang penjelasan terkait materi ordo $3 \times 3$, seharusnya ada penjelasan mengenai kofaktor dan minor

\section{Hasil Revisi}

Warna sudah diganti dengan warna yang sesuai

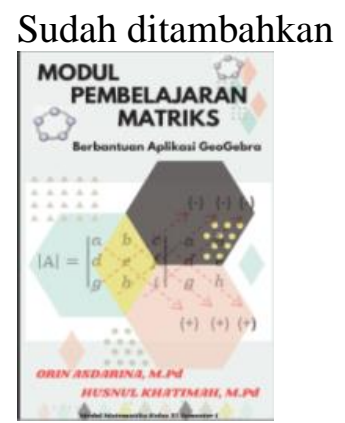

Sudah ditambahkan

$$
\begin{aligned}
& {\left[\begin{array}{ll}
20 & 10.000 \\
15 & 20.000
\end{array}\right] \Rightarrow\left[\begin{array}{ll}
20 & 10.000 \\
15 & 20.000
\end{array}\right] \longrightarrow \text { Baris } 1} \\
& 1 \quad 1 \\
& \text { Kolom! Kolom? }
\end{aligned}
$$

Sudah ditambahkan

Setiap LKS sudah ditambahkan soal berbentuk cerita

Sudah ditambahkan materi tentang ordo $3 \times 3$, dan penjelasan mengenai kofaktor dan minor 
DOI: https://doi.org/10.24127/ajpm.v10i2.3515

\begin{tabular}{ll}
\hline \multicolumn{1}{c}{ Rancangan Awal } & \multicolumn{1}{c}{ Hasil Revisi } \\
\hline Tidak ada penjelasan mengenai Identitas suatu & Sudah ditambahkan materi \\
matriks, materi identitas diperlukan untuk $A \cdot x=B$ & mengenai identitas matriks \\
maka $x=A^{-1} . B$ & \\
Pada perkalian matriks harus ada kesimpulan & Sudah ditambahkan \\
bagaimana syarat agar 2 buah matriks dapat & \\
dikalikan. & \\
\hline
\end{tabular}

2) Analisis Uji Coba Keterbacaan

Pada tahap evaluasi selanjutnya dilakukan ujicoba keterbacaan yang bertujuan untuk mengetahui kesalahankesalahan dalam penulisan modul pembelajaran yang dikembangkan, seperti kesalahan pengetikan, kata-kata yang terlewatkan, serta kesalahan penggunaaan huruf besar/kecil.Subjek pada uji coba kelompok kecil terdiri dari enam orang siswa kelas XI SMA Negeri Unggul Harapan Persada. Data uji coba keterbacaan digunakan sebagai dasar untuk memperbaiki kualitas modul pembelajaran yang dikembangkan sebelum memasuki tahap uji coba lapangan.

Berdasarkan hasil analisis penilaian siswa terhadap modul pada uji coba keterbacaan menunjukkan bahwa ratarata total penilaian siswa mencapai 3,4 yang artinya setiap kriteria pada modul sudah masuk kategori baik, seperti kata yang digunakan dalam modul tidak ambigu, gambar yang disajikan memudahkan dalam memaha-mi materi, dan soal yang disajikan dalam modul jelas/mudah dipahami.

Adapun komentar siswa yang didapat pada ujicoba kelompok kecil adalah selama ini belum ada modul pembelajaran matriks di Sekolah serta pembelajaran materi matriks belum dapat dipahami dengan baik.

\section{Implementation (Implementasi)}

Tahap implementasi merupakan tahap uji coba di lapangan. Adapun pada tahap ini, modul pembelajaran yang sudah valid digunakan dalam proses pembelajaran di kelas. Uji coba kelompok kecil dilakukan pada 14 siswa kelas XI IPS SMA Negeri Unggul Harapan Persada, yang diuji cobakan adalah modul pembelajaran matriks dan soal tes hasil belajar. Uji coba ini dilaksanakan selama 4 kali pertemuan. Adapun tujuan dari implemetasi adalah untuk mengamati proses pembelajaran (menggunakan lembar observasi pembelajaran), respon siswa terhadap pembelajaran matriks berbantuan aplikasi GeoGebra (menggunakan angket respon siswa), serta tes yang diberikan diakhir pembelajaran untuk melihat hasil belajar siswa setelah mengikuti pembelajaran dengan menggunakan modul pembelajaran matriks berbantuan GeoGebra.

E. Evaluation (Evaluasi)

1. Analisis Uji Kepraktisan

Analisis kepraktisan dilakukan untuk melihat kualitas modul pembelajaran yang dikembangkan berdasarkan respon siswa setelah menggunakan modul pembelajaran dan hasil observasi keterlaksanaan pembelajaran.

\section{a. Analisis Uji Coba Lapangan}

1) Angket respon siswa

Angket respon siswa digunakan untuk menilai keefektifan perangkat pembelajaran ditinjau dari aspek kemudahan dan keterbantuan. Tabulasi hasil angket respon siswa dapat dilihat pada Tabel 8 . 
DOI: https://doi.org/10.24127/ajpm.v10i2.3515

Tabel 8. Hasil angket respon siswa

\begin{tabular}{lcc}
\hline \multicolumn{1}{c}{$\begin{array}{c}\text { Aspek yang } \\
\text { Direspon }\end{array}$} & $\begin{array}{c}\text { Persentase } \\
(\mathbf{\%})\end{array}$ & Kategori \\
\hline $\begin{array}{l}\text { Penilaian } \\
\text { terhadap } \\
\text { kegiatan } \\
\text { pembelajaran } \\
\text { menggunakan } \\
\text { modul }\end{array}$ & $82,7 \%$ & $\begin{array}{c}\text { Sangat } \\
\text { Baik }\end{array}$ \\
$\begin{array}{l}\text { GeoGebra } \\
\text { Penilaian } \\
\text { terhadap modul }\end{array}$ & & \\
$\begin{array}{l}\text { yang digunakan } \\
\text { dalam } \\
\text { pembelajaran }\end{array}$ & $85,9 \%$ & $\begin{array}{c}\text { Sangat } \\
\text { Baik }\end{array}$ \\
\hline \multicolumn{1}{c}{ Total } & $\mathbf{8 2 , 6 \%}$ & $\begin{array}{c}\text { Sangat } \\
\text { Baik }\end{array}$ \\
\hline
\end{tabular}

Berdasarkan Tabel 8, persentase respon siswa terhadap pembelajaran mencapai $82,6 \%$ yang menunjukkan respon siswa sangat baik terhadap pembelajaran menggunakan modul pembelajaran yang dikembangkan. Hal ini berarti modul pembelajaran yang dikembangkan dapat terlaksana dengan sangat baik.

\section{2) Observasi Keterlaksanaan \\ Pembelajaran \\ Observasi keterlaksanaan} pembelajaran digunakan untuk menilai kepraktisan modul pembelajaran yang telah dikembangkan dalam proses pembelajaran. Hasil observasi keterlaksanaan pembelajaran selama proses pembelajaran berlangsung menunjukkan persentase rata-rata 83.33\%. Berdasarkan pedoman kualifikasi keterlaksanaan pembelajaran yang telah dikembangkan, maka modul pembelajaran yang dikembangkan memenuhi kriteria praktis. Hal ini berarti modul pembelajaran yang dikembangkan dapat terlaksana dengan sangat baik dalam pembelajaran dan mudah digunakan.

\section{Analisis Keefektifan}

Analisis keefektifan dilakukan untuk melihat efektifnya proses pembelajaran menggunakan modul pembelajaran yang dikembangkan berdasarkan tes hasil belajar siswa. Tes hasil belajar siswa diperoleh dari tes akhir yang diberikan setelah pembelajaran dilaksanakan. Hasil tes yang diperoleh disajikan dalam Tabel 9.

Tabel 9. Hasil tes siswa pada tahap uji coba

\begin{tabular}{ccc}
\hline Uraian & \multicolumn{2}{c}{ Tes Hasil Belajar } \\
\cline { 2 - 3 } & Jumlah & Persentase \\
\hline $\begin{array}{c}\text { Peserta didik } \\
\text { yang tuntas }\end{array}$ & 12 & $85,7 \%$ \\
\hline $\begin{array}{c}\text { Peserta didik yang } \\
\text { tidak tuntas }\end{array}$ & 2 & $14,3 \%$ \\
\hline
\end{tabular}

Tabel 9 menunjukkan bahwa tes hasil belajar siswa setelah mengikuti pembelajaran sebanyak $85,7 \%$ siswa tuntas dan berdasarkan syarat ketuntasan yang ditetapkan, maka hasil ketuntasan belajar siswa sudah tercapai. Semua kriteria keefektifan sudah memenuhi kriteria yang ditetapkan, maka modul pembelajaran yang dikembangkan sudah efektif.

Prosedur yang dilakukan dalam mengembangkan dan menghasilkan modul pembelajaran matriks berbantuan Geogebra yang valid, praktis dan efektif melaui tahapan ADDIE : Analysis (analisis), Design (desain), Development (pengembangan), Implementation (pelaksanaan), dan Evaluation (evaluasi).

Hasil akhir dari proses pengembangan ini menghasilkan produk berupa modul pembelajaran yang telah diuji kevalidan, kepraktisan dan keefektifannya. Beberapa hal yang menjadi temuan dalam penelitian ini adalah sebagai berikut: 
A. Kevalidan Modul Pembelajaran

Terdapat dua kriteria penting dalam proses pengembangan sebuah modul, yakni validasi isi dan manfaat modul setelah di uji cobakan. Tahap evaluasi pertama yang dilakukan terhadap modul pembelajaran yang dikembangkan adalah validasi oleh para pakar (team expert) yang terdiri dari ahli materi dan Geogebra serta ahli media.Kegiatan ini bertujuan untuk mereview produk awal, memberi masukan untuk perbaikan. Proses validasi ini disebut dengan Expert Judgem\&ent(pertimbangan para ahli), yang dilakukan dengan diskusi kelompok atau Focus Group Discussion (FGD).

Dari hasil FGD diperoleh beberapa masukan untuk perbaikan modul pembelajaran yang akan dihasilkan. Proses validasi modul pembelajaran dilakukan dua kali walaupun hasil analisis data lembar validasi modul pembelajaran yang dikembangkan sudah masuk dalam kategori valid, tetapi perlu dilakukan validasi kedua kalinya agar modul yang dikembangkan sesuai dengan saran dan masukan yang diberikan oleh para validator.

Validasi modul yang dilakukan bertujuan untuk menguji kesesuaian modul yang dikembangkan dengan materi Matriks yang diajarkan di sekolah.Secara keseluruhan hasil validasi isi modul yang dikembangkan dengan rata-rata 4.5 (Sangat Baik).

Sedangkan hasil validasi oleh ahli media secara keseluruhan rata-rata dari semua indikator untuk media sebesar 4.5 (Sangat Baik).

Modul pembelajaran yang dikembangkan dikatakan valid apabila skor rata-rata penilaiain kevalidan masing-masing memenuhi kriteria minimal baik. jadi dapat disimpulkan berdasarkan hasil analisis lembar validasi ini maka modul pembelajaran materi matriks berbantuan aplikasi Geogebra masuk dalam kategori valid, dengan rata-rata keseluruhan 4,5 (sangat baik). Hal ini sejalan dengan penelitian (Isharyadi \& Ario, 2018) modul pembelajaran yang dikembangkan valid dan layak digunakan.

\section{B. Kepraktisan Modul Pembelajaran}

Berdasarkan hasil ujicoba lapangan yang dilaksanakan di kelas XI IPS dengan jumlah siswa 14 orang, siswa dapat menggunakan modul pembelajaran dengan baik yang ditunjukkan oleh respon yang diberikan siswa yaitu diperoleh persentase ratarata $82,6 \%$ dengan klasifikasi sangat baik. Hal ini menunjukkan bahwa modul pembelajaran materi matriks berbantuan geogebra membantu dan memudahkan siswa dalam memahami materi matriks. Kemudian hasil observasi yang diberikan oleh observer diperoleh persentase rata-rata 83,33\% dengan kategori praktis. Hal ini menunjukkan bahwa perangkat pembelajaran yang dikembangkan praktis digunakan dalam proses pembelajaran. Hal ini sesuai dengan penelitian yang telah dilakukan oleh (Vidanti, Mahayukti, \& Ariawan, 2016) media GeoGebra mendapat tanggapan sangat positif dari guru maupun siswa, sehingga perangkat tersebut dapat dikatakan praktis. Serta (Lihu et al., 2019) bahwasanya respon siswa yang diajarkan selama menggunakan media pembelajaran berbantuan aplikasi Geogebra dikategorikan cenderung positif.

\section{Keefektifan Modul Pembelajaran.}

Berdasarkan tes hasil belajar siswa didapat bahwasanya dari 14 siswa yang mengikuti tes hasil belajar, siswa 
yang tuntas 12 siswa dengan persentase $85,7 \%$ dan yang tidak tuntas 2 siswa dengan persentase $14,3 \%$. Ketuntasan tes hasil belajar didapat ternyata banyak siswa yang tuntas melebihi $85 \%$, maka ketuntasan belajar siswa sudah tercapai. Hal ini sejalan hasil penelitian (Hamidah et al., 2020) media pembelajaran Geogebra berpengaruh terhadap motivasi dan hasil belajar peserta didik. (Akhini\&Mahmudi, 2016) bahwa pemanfaatan program GeoGebra dalam proses pembelajaran berpengaruh secara signifikan terhadap hasil belajar dan motivasi belajar siswa. Serta (Aufa, Zubainur, \& Munzir, 2021) pengembangan perangkat pembelajaran berbantuan Geogebra dikatakan efektifterlihat dari rata-rata aktivitas on task siswa baik, rata-rata aktivitas siswa juga baik, adanya peningkatan skor tes formatif, guru dan siswa memberikan respon positif terhadap penggunaan perangkat pembelajaran di kelas.

Berdasarkan hasil penelitian yang telah dikemukakan, bahwasanya modul pembelajaran matriks berbantuan aplikasi GeoGebra yang telah dikembangkan memberikan dampak positif terhadap hasil belajar siswa dan penerapan modul dalam proses pembelajaran membuat siswa termotivasi untuk mempelajari materi matriks.

\section{KESIMPULAN DAN SARAN}

Dari hasil penelitian yang telah dilakukan didapat kesimpulan yaitu, kualitas modul pembelajaran matriks berbantuan aplikasi GeoGebra yang telah dikembangkan masuk dalam kategori valid dengan skor rata-rata 4,5 (Sangat Baik), praktis dengan persentase rata-rata $82,6 \%$ (Sangat Baik) dan efektif digunakan dalam pembelajaran di kelas.
Penelitian ini hanya di ujicobakan pada skala yang kecil yaitu hanya satu kelas dan hanya pada satu sekolah, jadi disarankan agar penelitian ini bisa untuk dilanjutkan dalam skala yang lebih besar agar modul pembelajaran yang telah dikembangkan dapat dimanfaatkan oleh banyak siswa dan guru yang tertarik untuk mempelajari matriks dengan suasana yang baru dan mudah untuk digunakan.

\section{DAFTAR PUSTAKA}

Akhini, A.,\& Mahmudi, A. (2016). Pengaruh Pemanfaatan Cabri 3D dan GeoGebra pada Pembelajaran Geometri Ditinjau dari Hasil Belajar dan Motivasi. Jurnal Pendidikan Matematika dan Sains, 3(2), 91-100. https://doi.org/10.21831/jpms.v6i2. 10922

Aminah, S., \& Radita, N. (2020). Pengembangan Modul Pembelajaran Aljabar Linier dan Matriks dengan Pendekatan Inkuiri untuk Mahasiswa Teknik Informatika. MUST: Journal of Mathematics Education, Science and Technology. https://doi.org/10.30651/must.v5i2. 5884

Arbain, N., \& Shukor, N. A. (2015). The EArbain, N., \& Shukor, N. A. (2015). The Effects of GeoGebra on Students Achievement. Procedia - Social and Behavioral Sciences.https://doi.org/10.1016/j.s bspro.2015.01.356

Aufa, N., Zubainur, C.M., \& Munzir, S. (2021). Pengembangan Pembelajaran Model Missouri Mathematics Project (MMP) Berbantuan Software Geogebra untuk Meningkatkan Pemahaman Konsep Siswa. Jurnal Inovasi Penelitian, 1(11), 2377-2393. 
DOI: https://doi.org/10.24127/ajpm.v10i2.3515

https://doi.org/10.47492/jip.v1i11. 484

Ekayanti, A. (2017). Pengembangan Modul Irisan Kerucut Berbantuan Geogebra. AKSIOMA: Jurnal Program Studi Pendidikan Matematika, 6(3), 308-314

Hamidah, N., Afidah, I. N., Setyowati, L. W., Sutini, S., \& Junaedi, J. (2020). Pengaruh Media Pembelajaran Geogebra Pada Materi Fungsi Kuadrat Terhadap Motivasi dan Hasil Belajar Peserta Didik. Journal of Education and Learning Mathematics Research (JELMaR), 1(1), 15-24. https://doi.org/10.37303/jelmar.v1i 1.2

Hohenwarter, M., \& Lavicza, Z. (2007). Mathematics Teacher Development with ICT: Towards an International GeoGebra Institute. Proceedings of the British Society for Research into Learning Mathematics.

Isharyadi, R., \& Ario, M. (2018). Pengembangan Modul Berbantuan Geogebra Pada Perkuliahan Geometri Transformasi. Guru Tua: Jurnal Pendidikan Dan Pembelajaran, 1(1), 1-8. https://doi.org/10.31970/gurutua.v1 i1.2

Korenova, L. (2017). GeoGebra in teaching of primary school mathematics. International Journal for Technology in Mathematics Education.https://doi.org/10.1564/t me_v24.3.08

Lihu, I., Ma'rufi, \& Ilyas, M. (2019). Pembelajaran Matematika dengan Menggunakan Media Pembelajaran Berbantuan Aplikasi Geogebra untuk Meningkatkan Higher Order Thinking Skills Siswa Kelas VIII SMPB 6 Palopo. Jurnal Penelitian Matematika Dan Pendidikan
Matematika: Proximal, 2(2), 39-52 Mahmudi, A. (2010). Membelajarkan Geometri dengan Program GeoGebra. Prosiding Seminar Nasional Matematika Dan Pendidikan Matematika.

Rafiyanti, I. (2017). Pengembangan Modul Pembelajaran Matematika dengan Pendekatan Saintifik pada Materi Matriks Kelas XI SMA. Prosiding Seminar Nasional Pendidikan FKIP UNTIRTA.

Rochmad. (2012). Desain Model Pengembangan perangkat Pembelajaran Matematika. Kreano: Jurnal Matematika Kreatif-Inovatif, 3(1), 59-72. https://doi.org/https://dx.doi.org/10 $.15294 /$ kreano.v3i1.2613

Sari, F. komala, Farida, \& M.Syazali. (2016). Pengembangan Media Pembelajaran (Modul) berbantuan Geogebra Pokok Bahasan Turunan. Al-Jabar: Jurnal Pendidikan Matematika, 7(2), 135-152.

Vidanti, N. P. U., Mahayukti, I. G. A., \& Ariawan, I. P. W. (2016). Pengembangan LKS Berbasis Open Source Software Geogebra Untuk Meningkatkan Prestasi Belajar Matematika Siswa Kelas VIII SMP Negerti 1 Singaraja. Jurnal Wahana Matematika Dan Sains, 10(2), 48-57.

Zaningsih, R. D. (2018). Pengembangan Aplikasi E-Modul Mobile Pembelajaran Matematika Berbasis Android Studio Pokok Bahasan Matriks (Skripsi). Diakses dari http://repository.radenintan.ac.id/id /eprint/4063 